\title{
Circulating microRNAs and liquid biopsy: murine xenograft models for technical validation of clinical protocols
}

\author{
Jessica Gasparello1, Matteo Allegretti ${ }^{2}$, Chiara Papi ${ }^{1}$, Elena Giordani², Patrizio Giacomini², Roberto \\ Gambari ${ }^{1,3}$, Alessia Finotti ${ }^{1}$ \\ 'Department of Life Sciences and Biotechnology, Ferrara University, Ferrara 44121, Italy. \\ ${ }^{2}$ Oncogenomics and Epigenetics, IRCCS Regina Elena National Cancer Institute, Rome 00144, Italy. \\ ${ }^{3}$ Interuniversity Consortium for Biotechnology (CIB), Trieste 34149, Italy.
}

Correspondence to: Prof. Roberto Gambari, Department of Life Sciences and Biotechnology, Biochemistry and Molecular Biology Section, Ferrara University, Via Fossato di Mortara 74, Ferrara 44121, Italy. E-mail: gam@unife.it

How to cite this article: Gasparello J, Allegretti M, Papi C, Giordani E, Giacomini P, Gambari R, Finotti A. Circulating microRNAs and liquid biopsy: murine xenograft models for technical validation of clinical protocols. J Cancer Metastasis Treat 2019;5:52. http://dx.doi.org/10.20517/2394-4722.2019.17

Received: 22 Feb 2019 First Decision: 28 Mar 2019 Revised: 17 Apr 2019 Accepted: 5 May 2019 Published: 26 Jun 2019

Science Editor: Ciro Isidoro Copy Editor: Cai-Hong Wang Production Editor: Jing Yu

\begin{abstract}
In oncology, liquid biopsy is applied to detect with high efficiency clinically relevant analytes, such as tumor cells, cell-free nucleic acids, and exosomes in peripheral blood and other body fluids of cancer patients. Liquid biopsy is considered one of the most advanced non-invasive diagnostic systems useful, in the next future, for enabling personalized treatments in precision medicine. Medical actions include, but are not limited to, early diagnosis, staging, prognosis, anticipation (lead time) and prediction of therapy responses, as well as follow up. Experimental system for validation of the proposed liquid biopsy approaches is highly needed. In this review article we will discuss the establishment of xenotransplanted mouse model systems for the validation of liquid biopsy protocols aimed to identify changes in the miRNA plasma content. Human colon cancer HT-29 and LoVo cells have been xenotransplanted and miR-221-3p and miR-222-3p have been comparatively analyzed in cultured HT-29 and LoVo cells, xenotransplants and plasma samples.
\end{abstract}

Keywords: Liquid biopsy, circulating tumor RNA, microRNA, xenograft

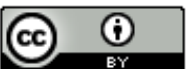

(C) The Author(s) 2019. Open Access This article is licensed under a Creative Commons Attribution 4.0 International License (https://creativecommons.org/licenses/by/4.0/), which permits unrestricted use sharing, adaptation, distribution and reproduction in any medium or format, for any purpose, even commercially, as long as you give appropriate credit to the original author(s) and the source, provide a link to the Creative Commons license, and indicate if changes were made. 


\section{LIQUID BIOPSY: A NEW FRONTIER FOR CANCER DIAGNOSTICS}

In the field of cancer diagnosis and treatment, liquid biopsy is a new diagnostic tool that investigates circulating tumor cells (CTC) and/or cell-free nucleic acids in the peripheral blood [Figure 1A]. Liquid biopsy is considered one of the most advanced non-invasive diagnostic systems. It provides key molecular information relevant to important clinical decisions and, being "longitudinal" (it can be repeated as many times as needed), it fits the idea of precision medicine possibly more than other "static" techniques based on the analysis of tissue nucleic acids ${ }^{[-5]}$. Diagnostic actions made possible by liquid biopsy include, but are not limited to, early diagnosis, staging, prognosis, prediction of therapy response and follow up during therapeutic intervention ${ }^{[6-11]}$.

In addition to the use of CTCs ${ }^{[12-15]}$ and circulating tumor DNA (ctDNA) ${ }^{[16-18]}$, other important targets for liquid biopsy are circulating microRNAs (miRNAs) ${ }^{[19-24]}$, a family of small (19 to 25 nucleotides in length) noncoding RNAs playing important roles in controlling post-transcriptional gene expression. Regulatory miRNAs reduce protein synthesis through selective interactions with complementary sequences of target messenger RNAs (mRNAs) ${ }^{[25-27]}$. Single or multiple mRNAs can be targeted at their $3^{\prime}-\mathrm{UTR}$, CDS, 5'-UTR sequences, and it is calculated that more than $60 \%$ of human mRNAs are microRNA targets ${ }^{[26]}$. Dysregulation of microRNAs has been associated with a variety of human pathologies, including cancer ${ }^{[28-31]}$. In this case miRNAs behave both as tumor promoters (oncomiRNAs and metastamiRNAs) and tumor suppressor molecules ${ }^{[29]}$, depending on their mRNA targets (oncosuppressor mRNAs or mRNA coding oncoproteins, respectively) with opposing activity on cancer cells. Based on this, it is not surprising that circulating cellfree miRNAs have been actively investigated as liquid biopsy analytes. OncomiRNAs are abundant in several extracellular body fluids, where they are protected and stabilized by exosome-like structures and small intraluminal vesicles produced by a variety of cells (including cancer cells) ${ }^{[32-36]}$. Hence, elevated levels of several miRNAs (including miR-221, miR-222, miR-141, miR-92a, miR-21, miR-155, miR- 506, miR-4316, miR-4772-3p, and miR-29a) are present in the blood from patients with colorectal carcinomas (CRC) and may contribute to diagnosis and prognosis ${ }^{[21,37-42]}$. Furthermore, is well established that miRNAs may help in monitoring therapeutic approaches. For instance, Ogata-Kawata et al. ${ }^{[22]}$ reported that serum exosomal miRNA levels (let-7a, miR-1229, miR-1246, miR-150, miR-21, miR-223, and miR-23a) were higher in CRC patients than controls, were already detectable at early disease stages, and that they were significantly downregulated after surgical resection.

\section{TECHNOLOGIES FOR MICRORNA ANALYSIS}

In order to quantify miRNAs in the plasma and other body fluids isolated from cancer patients, several types of technologies for RNA analysis have been proposed ${ }^{[43-51]}$. Quantitative real-time PCR (RT-qPCR ${ }^{[52]}$, NGS RNA sequencing ${ }^{[53]}$, miRNA microarray analysis ${ }^{[54]}$, and digital $\mathrm{PCR}^{[55]}$ are the most used [Table 1] and can be employed not only for tissue or cells but also for highly diluted samples, such as body fluids. One of the major limits of RT-qPCR and ddPCR is the limited number of miRNAs that can be quantified for single run. This problem was partially solved by introduction of TaqMan low density arrays, that allows to quantify the content of a significant number of miRNAs (about 700 miRNAs) using PCR-based methods ${ }^{[56]}$. In addition to these methodologies, other technologies have been described for direct miRNA detection from serum samples. For example, Chapin et al..$^{[57]}$ proposed rolling circle amplification (RCA) based on the use of a universal adapter ligated to the targets captured on encoded gel microparticles. The system allows the multiplexed profiling of miRNA at sub-femtomolar concentration. Interestingly, Williams et al. ${ }^{[58]}$ proposed a miRNA detection technique able to amplify miRNAs directly in body fluids, avoiding upstream sample preparation. The technique, based on isothermal target amplification, has a sensitivity positioned in the femtomolar range. Other conventional technologies normally proposed for miRNA detection in cells or tissues, such as northern blotting ${ }^{[59]}$, are not suitable for miRNA detection in body fluids, due to the low sensitivity of the technology, requiring therefore large amounts of RNA. Other unconventional miRNA 

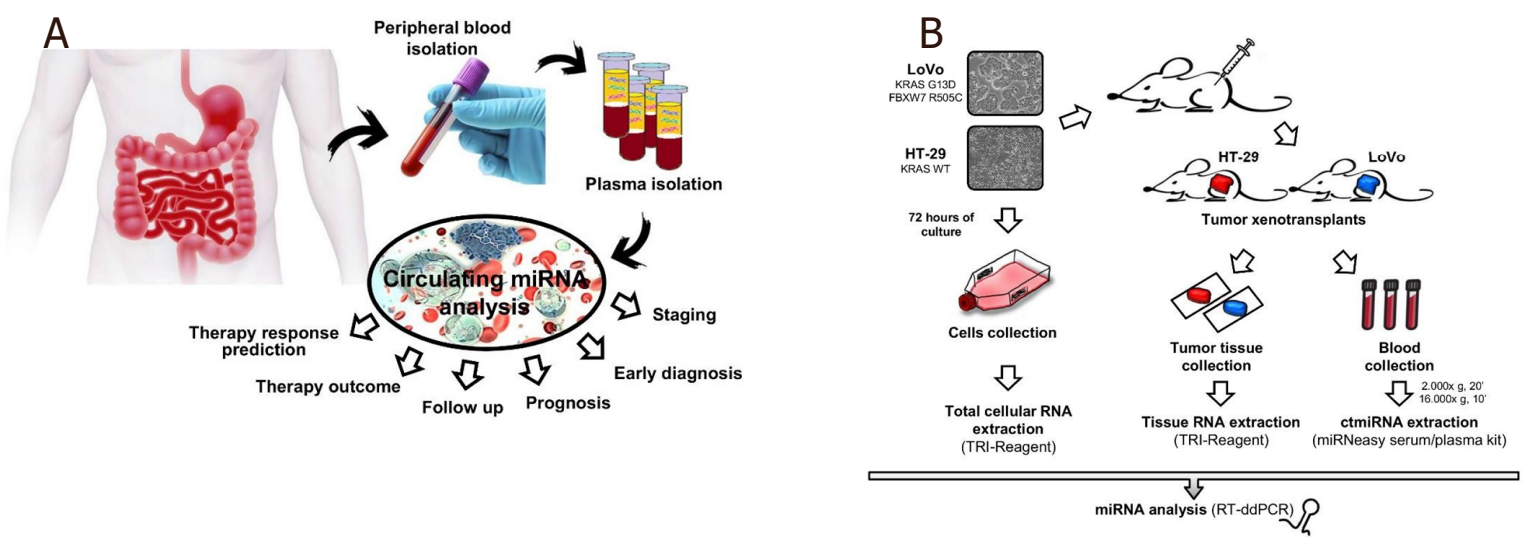

Figure 1. Flow chart describing the experimental in vivo model system. All the procedures have been performed according to Directive 2010/63/EU and Italian Decree Law 26/2014. They were approved by the EU Research Executive Agency, the Intramural Regina Elena Board for Animal Welfare, and the Italian Ministry of Health (700-2015-PR, dated July 17, 2015). Tumor xenotransplants were established by inoculating $3 \times 10^{6}$ cells from the HT-29 and LoVo cell lines in the flank of 4-month old Nu/CD1 mice (Charles River Laboratories, Italy). Xenotransplants were allowed to grow to two different sizes (300 and $1000 \mathrm{~mm}^{3}, 6$ mice per group for each of the two cell lines). Tumors were taken at sacrifice along with blood. Frozen tissues were used as the source of miRNAs. Blood was collected in $6 \mathrm{~mL} B D$ Vacutainer $\mathrm{K} 2 \mathrm{E}$ tubes $(\mathrm{BD}, 368857)$ and centrifuged within $1 \mathrm{~h}$ at $2000 \times \mathrm{g}$ for $20 \mathrm{~min}$ at $4{ }^{\circ} \mathrm{C}$. Plasma was recovered and further centrifuged at $16,000 \times g$ for $10 \mathrm{~min}$ at $4{ }^{\circ} \mathrm{C}$ to remove cell debris, and stored at $-80^{\circ} \mathrm{C}$ until extraction

\section{Table 1. Technologies applied to miRNA detection}

\begin{tabular}{|c|c|c|c|}
\hline Technologies & Biological fluid & Major results obtained & Ref. \\
\hline $\begin{array}{l}\text { Real-time } \\
\text { quantitative PCR }\end{array}$ & Plasma & $\begin{array}{l}\text { RNA was isolated from human plasma samples of healthy donor and the content of } \\
\text { three miRNAs chosen to represent moderate- to low-abundance plasma miRNAs } \\
\text { (miR-15b, miR-16, and miR-24) was evaluated using TaqMan RT-qPCR assays }\end{array}$ & {$[52]$} \\
\hline $\begin{array}{l}\text { NGS RNA } \\
\text { sequencing }\end{array}$ & Serum & $\begin{array}{l}\text { A NGS RNA sequencing (Solexa sequencing) approach, followed by RT-qPCR data } \\
\text { validation was employed to identify miRNAs able to predict prognosis of non- } \\
\text { small-cell lung cancer. Four miRNAs (miR- } 486, \text { miR-30d, miR-1 and miR-499) were } \\
\text { significantly associated with overall survival }\end{array}$ & [53] \\
\hline $\begin{array}{l}\text { MicroRNA } \\
\text { microarray analysis }\end{array}$ & Serum & $\begin{array}{l}\text { A global miRNA profiling was performed, using GeneChip miRNA Arrays } \\
\text { (Affymetrix) in prostate adenocarcinoma transgenic mouse models identifying } 46 \\
\text { miRNAs significantly altered compared to healthy controls }\end{array}$ & {$[54]$} \\
\hline Droplet digital PCR & Plasma & $\begin{array}{l}\text { Droplet digital PCR platform was used to assess levels of miRNAs (miR-221, miR- } \\
222 \text { and miR-141) released into the culture supernatants of colorectal carcinoma } \\
\text { cell lines and mouse blood plasma obtained from xenograft models }\end{array}$ & {$[55]$} \\
\hline $\begin{array}{l}\text { MicroRNA low } \\
\text { Density Arrays }\end{array}$ & Plasma & $\begin{array}{l}\text { Circulating miRNAs profile was examined in mice bearing human small cell lung } \\
\text { cancer tumor xenografts using human TaqMan Low Density Array } \\
\text { The analysis allows to identify a panel of differentially expressed miRNAs, in a } \\
\text { stage dependent manner }\end{array}$ & {$[56]$} \\
\hline $\begin{array}{l}\text { Rolling circle } \\
\text { amplification }\end{array}$ & Serum & $\begin{array}{l}\text { The rolling circle amplification of a universal adapter sequence selectively ligated } \\
\text { to targets captured on encoded gel microparticles is employed for multiplexed } \\
\text { profiling of miRNAs at sub-femtomolar concentration. The protocol was optimized } \\
\text { to cover a dynamic range of magnitude ( } 300 \text { aM to } 40 \text { pM). Moreover, miRNAs } \\
\text { can be directly detected in small quantities of unprocessed serum samples } \\
\text { avoiding RNA extraction or target-amplification steps }\end{array}$ & [57] \\
\hline $\begin{array}{l}\text { Isothermal } \\
\text { ramification } \\
\text { amplification } \\
\text { (RAM) }\end{array}$ & Plasma & $\begin{array}{l}\text { Isothermal RAM allows the direct amplification of miRNAs without upstream } \\
\text { sample preparation. The presence of microRNA promotes base-stacking } \\
\text { hybridization, and subsequent amplification between two universal strands, under } \\
\text { isothermal conditions. A sensitivity in the range of femtomolar is provided }\end{array}$ & {$[58]$} \\
\hline Northern blotting & Tissues & $\begin{array}{l}\text { An highly efficient microRNAs detection method based on northern blot analysis } \\
\text { was set-up using LNA (locked nucleic acid) probes able to increase the sensitivity } \\
\text { of at least } 10 \text {-fold compared to conventional DNA probes }\end{array}$ & [59] \\
\hline $\begin{array}{l}\text { Bead-based flow } \\
\text { Cytometry }\end{array}$ & Tissue/cell lines & $\begin{array}{l}\text { Oligonucleotide-capture probes complementary to miRNAs of interest were } \\
\text { coupled to carboxylated 5- micron polystyrene Beads impregnated with variable } \\
\text { mixtures of two fluorescent dyes each representing a single miRNA } \\
\text { After the reverse transcription miRNAs are amplified by polymerase chain reaction } \\
\text { and hybridized to the capture beads, beads were then analysed using a flow } \\
\text { cytometer capable of measuring bead colour }\end{array}$ & {$[60]$} \\
\hline
\end{tabular}


detection techniques have been proposed in recent years such as bead-based flow cytometry ${ }^{[60]}$ but at the moment they are employed only for miRNA detection in tissues or cellular samples.

\section{EXPERIMENTAL MODEL SYSTEMS FOR LIQUID BIOPSY}

Given the fast pace of technological evolution and the clinical complexity of human cancers, there is an increasing need for experimental in vivo systems and associated validation technologies. A robust analysis of bio-fluids must acknowledge the fact that liquid biopsy is a complex strategy requiring the achievements of several key points, including pre-analytical steps, post-analytical optimization, and careful selection of optimal analytes for specific biological queries. In vivo model systems might be very useful to address and isolate these many individual variables (that are both technical and biological), and validate complex multistep approaches. It is surprising, in this respect, that only few reports are available focusing on the use of animal models. In vivo model systems for the detection of circulating tumor cells and DNA have been proposed $^{[61-63]}$. These include injection of cancer cells into their orthotopic site of origin (e.g., a "recap" of natural tumor onset), injection of tumor cells directly into the bloodstream of the animal (to recap distant seeding), genetically engineered mouse and mice xenografted with patient-derived tumors ${ }^{[6-69]}$ (to mimic "true" tumors). As to the analysis of circulating miRNAs in these experimental settings, several reports are available ${ }^{[52,54-56,70,71]}[$ Table 2].

\section{Mice xenografted with human tumor cell lines or patient-derived tumor}

The pattern of circulating miRNAs has been extensively studied in mice xenografted with tumor cells and patient-derived tumors. Different independent studies firmly demonstrated that miRNAs released in the circulation by the tumor xenograft are distinct from the "background" mouse miRNAs pattern. This is a key point, since pre-existing miRNAs present in the mouse body fluids are identical in sequence to most human miRNAs and hence they might be a powerful confounding parameter, possibly altering conclusions and implications of any circulating miRNA signature. In this respect, the use of laboratory mouse strains has the advantage that its "background" mouse miRNA pattern is stable and easily quantifiable. Mitchell et al. ${ }^{[52]}$ demonstrated that several miRNAs originating from xenografted human prostate cancer cells are present in the mouse circulation (one of the most interesting being miR-141), and are readily measured in plasma, allowing a clear distinction between tumor xenografted and control tumor-free mice. Waters et al. ${ }^{[0]}$ observed a complex miRNAs dysregulation in the circulation of athymic nude mice subcutaneously injected with MDA-MB-231 cells. Some miRNAs (such as miR-10b) were undetectable in the circulation, others (miR195 and miR-497) were significantly decreased, miR-221 content did not change, and a positive correlation was observed between miR-497 and miR-195. This study highlighted distinct roles of miRNA subsets in the circulation and in disease dissemination and progression, all of which may be candidates as molecular targets for diagnosis as well as design of systemic therapy. Gasparello et al.$^{[5]}$ studied liquid biopsy in mice bearing CRC xenografts, demonstrating gateways regulating the levels of circulating tumor-derived miRNAs (ctmiRNAs), e.g., cell-specific roadblocks that determine whether a given cell xenotransplants releases or retains a specific miRNA. These roadblocks are often not present in cultured cells, and build "barriers" to detection in a liquid biopsy format.

\section{Genetically engineered mouse model systems}

Genetically engineered mouse models (GEMMs) manipulate target oncogene or tumor suppressor expression in mice in order to promote tumor development. Transgenic and knockout GEMMs have provided important models for identifying tumor-associated and metastasis-associated genes that can lead to tumor formation and disease progression. In addition, GEMMs have been applied to the development of liquid biopsy methods based on the analysis of circulating microRNAs. Selth et al.$^{[54]}$ performed a global miRNA profiling and identified a set of miRNAs exhibiting significantly altered serum levels in transgenic mice models of prostate cancer (i.e., Transgenic Adenocarcinoma of Mouse Prostate mice). Global miRNA profiling identified 46 
Table 2. Examples of experimental systems to study miRNA content in liquid biopsy

\begin{tabular}{|c|c|c|c|}
\hline Experimental mouse system & miRNA studied & Major results obtained & Ref. \\
\hline $\begin{array}{l}\text { Mouse models of prostate cancer } \\
\text { xenografted with } 22 \text { Rv1 human } \\
\text { prostate cancer- derived cells }\end{array}$ & miR-141-3p & $\begin{array}{l}\text { MicroRNAs derived from human prostate cancer } \\
\text { xenografts are readily measured in plasma of mouse } \\
\text { models allowing a clear distinction between tumor- } \\
\text { xenografted mice and controls }\end{array}$ & {$[52]$} \\
\hline $\begin{array}{l}\text { Transgenic mouse model of } \\
\text { prostate cancer }\end{array}$ & $\begin{array}{l}\text { miR-141-3p miR-375 miR- } \\
298 \text { miR-346 }\end{array}$ & $\begin{array}{l}\text { Global miRNA profiling allows to identified a set of ten } \\
\text { miRNAs significantly altered in serum of transgenic mice } \\
\text { compared to healthy controls }\end{array}$ & {$[54]$} \\
\hline $\begin{array}{l}\text { Mice bearing colorectal carcinoma } \\
\text { cell lines xenografts }\end{array}$ & $\begin{array}{l}\text { miR-141-3p miR-221-3p } \\
\text { miR-222-3p }\end{array}$ & $\begin{array}{l}\text { Evidences of gateways regulating the levels of circulating } \\
\text { miRNA }\end{array}$ & {$[55]$} \\
\hline $\begin{array}{l}\text { Mouse models bearing human } \\
\text { small cell lung cancer (SCLC) } \\
\text { tumor xenografts }\end{array}$ & $\begin{array}{l}\text { miR-95 miR-141-3p miR- } \\
\text { 200a-3p miR-200b-3p } \\
\text { miR-200c-3p miR-210- } \\
\text { 3p miR-335-3p miR-375 } \\
\text { miR-429 }\end{array}$ & $\begin{array}{l}\text { A panel of } 10 \text { miRNAs are dysregulated in tumor bearing } \\
\text { mouse models. The same miRNAs were also confirmed to } \\
\text { be altered in stage dependent manner in plasma isolated } \\
\text { from SCLC patients }\end{array}$ & {$[56]$} \\
\hline $\begin{array}{l}\text { Mouse models of breast cancer } \\
\text { xenografted with MDA-MB-231 } \\
\text { cells }\end{array}$ & $\begin{array}{l}\text { miR-10b-5p miR-195-5p } \\
\text { miR-497-5p miR-221-3p }\end{array}$ & $\begin{array}{l}\text { A complex miRNA dysregulation in the circulation athymic } \\
\text { nude xenografted mice was detected compared to tumor- } \\
\text { free controls }\end{array}$ & {$[70]$} \\
\hline $\begin{array}{l}\text { Foxp3 heterozygous Scurfy } \\
\text { mutant (Foxp } 3^{\text {st/+ }} \text { ) female mice. } \\
\text { The loss of Foxp3 expression, due } \\
\text { to the frameshift mutation leads } \\
\text { to the spontaneous development } \\
\text { of breast cancer and lung } \\
\text { metastases. }\end{array}$ & miR-200c-3p miR-141-3p & $\begin{array}{l}\text { Despite levels of miR-200c and miR-141 were found to } \\
\text { be lower in Foxp } 3^{\text {Sf } /+} \text { tumor cells than in normal breast } \\
\text { epithelial cells, plasma levels of miR- } 200 \mathrm{c} \text { and miR-141 in } \\
\text { the Foxp } 3^{\text {sf } /+} \text { mice increased during tumor progression } \\
\text { and metastasis }\end{array}$ & {$[71]$} \\
\hline
\end{tabular}

miRNAs at significantly altered levels in the serum of mice with advanced prostate cancer compared to healthy mice used as controls. Interestingly, four miRNAs altered in mice (mmu-miR-141, mmu-miR-298, mmu-miR-346 and mmu-miR-375) were also found to be expressed at higher levels in the serum of patients with metastatic prostate cancer compared with control subjects. Moreover, three of these (hsa-miR-141, hsa-miR-298 and hsa-miR-375) were upregulated in prostate tumors compared with normal prostate tissue, suggesting that they are directly released from the tumor into the blood as disease progresses. This study was the first to demonstrate that specific serum miRNAs (miR-141, miR-298 and miR-375) are common between human prostate cancer and a mouse model of the disease, highlighting the potential of such models for the discovery of novel biomarkers.

Zhang et al ${ }^{[7]}$ investigated FOXP3-inducible breast cancer cells, Foxp3 heterozygous Scurfy mutant (Foxp3 $\mathrm{sf} /+$ ) female mice, and patients with breast cancer for characterization of the formation and regulation of the miR-200 family in breast cancer cells and circulation. While levels of miR-200c and miR-141 were lower in Foxp3 sf/+ tumor cells than in normal breast epithelial cells, plasma levels of miR-200c and miR-141 in the Foxp3 sf/+ mice increased during tumor progression and metastasis. Interestingly, the levels of miR-200c and miR-141 were higher in plasma from patients with metastatic breast cancer than in plasma from those with localized breast cancer, with benign breast tumors, with a family history of breast cancer, or from healthy controls. The conclusion of the work reported by Zhang et al. ${ }^{[7]}$ supports the concept that miR-200c and miR-141 are regulated by a FOXP3-KAT2B axis in breast cancer cells, and circulating levels of miR-200c and miR-141 are potential biomarkers for early detection of breast cancer metastasis. Moreover, they highlight the idea that roadblocks evolve during the natural history of tumors.

\section{LIQUID BIOPSY IN MICE BEARING COLORECTAL CARCINOMA XENOGRAFTS OBTAINED AFTER IMPLANTATION OF HT-29 AND LOVO CARCINOMA CELLS}

Analysis of miRNA content has been recently performed in mice xenografted with colon cancer cell lines ${ }^{[55]}$. Among the different xenografted models the one based on the implantation of the HT-29 and LoVo CRC 
cells was found the most efficient for miRNA detection. The HT-29 cells were derived from a KRAS-WT, differentiated colorectal adenocarcinoma ${ }^{[72,73]}$, while LoVo cells (originally described as Dukes' type C, grade IV) harbor a heterozygous KRAS c.38G>A mutation $(\mathrm{G} 13 \mathrm{D})^{[74]}$.

\section{TUMOR XENOGRAFTS AND PLASMA PREPARATION}

Figure $1 \mathrm{~B}$ shows the study workflow based on the tumor xenografts as models for liquid biopsy to assess plasma levels of circulating miRNAs. In this study workflow, miRNAs are compared considering (1) in vitro cultured tumor cells; (2) tumor xenografts; and (3) blood plasma samples. The HT-29 and LoVo cell lines were selected as proxies of clinically evident cancers and sources of soluble analytes. MicroRNAs were extracted from both cell lines, matched tumor tissue and blood plasma samples and were then subjected to ddPCR and RT-qPCR analysis. Tumor xenotransplants were established by inoculating HT-29 and LoVo cells in the flank of 4-month old Nu/CD1 mice. Tumors were taken at sacrifice along with blood. Frozen tissues were used as the source of miRNAs. For the analysis of ctmiRNA, blood plasma was treated to disrupt exosomes and denature miRNA-binding proteins with QIAzol Lysis Reagent. After the addition of 400 amoles of celmiR-39-3p (an equalizer), total RNA was purified and reverse transcribed. Finally, droplet digital PCR (RTddPCR) assays for microRNA content analysis were performed to quantify the levels of miR-221-3 $\mathrm{p}^{[37,75]}$ and miR-222-3p $\mathrm{p}^{[76]}$. Droplets were analyzed using the QX200 Droplet Reader, and data analysis was performed with QuantaSoft version 1.7.4 (Bio-Rad, Hercules, CA, USA).

\section{TUMOR XENOGRAFTS AND PLASMA PREPARATION: MAJOR RESULTS}

The main point of this study is focused on determining whether the pattern of plasma miRNA content recapitulates HT-29 and LoVo cells and xenografted tumors. A representative example of miR-222-3p content is shown in Figure 2A and all the quantitative data for miR-221-3p and miR-222-3p are presented in Figure 2B. The miRNA levels were independently assessed by RT-qPCR and ddPCR results, obtaining similar results, as reported elsewhere ${ }^{[55]}$. Of course, in the quantitative analysis shown in Figure $2 \mathrm{~B}$ and concerning the plasma miRNA quantitation, we have taken into account the fact that cross-species miRNA homology might influence our in vivo results. Accordingly, we quantitated baseline, endogenous miR-221-3p and miR-222-3p levels in tumor-free, healthy nude mice. As expected (the sequences of mouse miR-221-3p and miR-222-3p are identical to those found in human cells) both RT-ddPCR and RT-qPCR demonstrated that circulating miRNAs were detectable even in the absence of tumor growth. However, the differences between tumor-bearing and tumor-free mice were clearly appreciable for both miRNAs. Figure $2 \mathrm{~B}$ shows that the miR-222-3p content is higher than miR-221-3p content in HT-29 and LoVo cells, and in tumor and plasma samples isolated from HT-29 and LoVo xenografted mice, despite the miR-222/miR-221 ratio is much higher in plasma in comparison with cell and tumors. This is consistent with the "gateway" effect mentioned above and discussed in deep in Gasparello et al ${ }^{[5]}$. This issue is particularly of interest, since detailed knowledge of the molecular mechanisms underlying the release of circulating analytes is still lacking. Alternatively, the in vivo response of xenotransplanted mice to tumor cell injection might contribute to the reported unbalanced content of miR-222/miR-221. The proposed system is expected to help in verifying the underlying cellular mechanisms.

\section{CONCLUSION}

Circulating miRNAs have been recently used as biological markers for early diagnosis, prognosis, prediction of response to therapy and clinical outcome, particularly in a liquid biopsy setting ${ }^{[1-11,77-79]}$. Liquid biopsy is a powerful tool applicable to all or most human cancers, including colorectal, lung, melanoma, and breast neoplasm $s^{[80,81]}$. From a more general viewpoint, tumor-xenotransplanted mice and other in vivo models may have an important role because they resolve biological variables from technical variables (such as handling and storage of biological fluids, pre-analytical processing, as well as DNA and RNA isolation protocols) that 

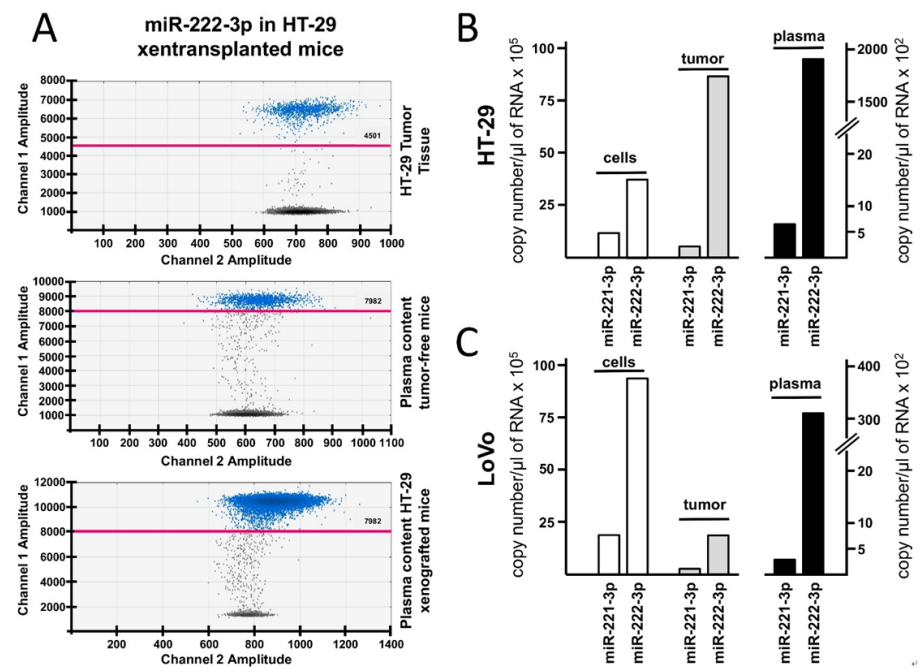

Figure 2. Content of microRNA miR-221-3p and miR-222-3p in HT-29 and LoVo cells, HT-29 and LoVo tumors and plasma isolated from HT-29 and LoVo xenotransplanted mice. A: representative Reverse Transcription droplet digital PCR plots performed using RNA isolated from tumor cells, plasma from tumor-free mice, and plasma from xenografted mice; B, C: content of miR-221-3p and miR-222-3p in cells, xenotransplanted tumors and plasma. RNA was extracted from frozen cell $\left(5 \times 10^{5}\right)$ pellets by the TRI-Reagent (Sigma-Aldrich, St.Louis, MO, USA), the procedure is described in Gasparello et al ${ }^{[55]}$. All RNAs were stored at $-80^{\circ} \mathrm{C}$ until the use. Reverse Transcription droplet digital PCR assays for microRNA expression analysis were performed to quantify the levels of miR-221-3p and miR-222-3p. 300 ng of total RNA (from cells and tissues) and the RNA isolated from $150 \mu \mathrm{L}$ of plasma were reverse transcribed and analyzed for miR-221-3p and miR-222-3p as described by Gasparello et al. ${ }^{[55]}$

might affect efficient marker detection by liquid biopsy ${ }^{[2,83]}$. Liquid biopsy of cancer is mainly based on the analysis of circulating tumor cells and/or cell-free nucleic acids in the peripheral blood of cancer patients, as well as in other body fluids suitable for diagnostic assessment. Among these, cerebrospinal fluid for tumors of the central nervous system, saliva for tumors affecting the head and neck, pleural effusion in the case of respiratory tract cancers and urine for urinary tract cancers. We propose that in vivo xenotransplant models monitoring miRNAs may find application in all the body fluids, contributing to assess the relevance of clinical liquid biopsy. The importance of in vivo model systems adds to the established role of liquid biopsy in complementing key limitations of surgical tissue biopsy. These include, but are not limited to: (1) invasiveness and inherent patient compliance; (2) a static representation of the tumor pathology strictly limited to the tumor tissue sampling; (3) ethical and practical issues preventing repeated tissue biopsy, particularly at unaccessible (or difficult to access) body sites; (4) tumor heterogeneity, especially during progression and metastatic dissemination (making multiple sampling necessary); (5) easier and real-time patient monitoring by non-invasive liquid biopsy. Therefore, although liquid biopsy approach still suffers from important drawbacks (fragmentation of cfDNA, instability of RNA, low yield of isolated samples to be analyzed and variable presence of normal DNA and RNA), this approach is generally deemed of great potential interest for future applications, patent development, and clinical trials, and mouse xenotransplants may be an important "shortcut" to application and technical streamlining.

Among possible application of mouse models we suggest: (1) studies on the relationship between the tumor size and the plasma miRNAs content (e.g., miR-222/miR-221 ratios); (2) analysis of the "gateway" hypothesis involved in the selection of released microRNAs (e.g., miR-221 and miR-222); (3) studies concerning the possible local and systemic responses of normal cells and tissues to xenotransplant procedure (tumor seeding); (4) analysis of the effects on miRNA plasma content on the susceptibility to experimental treatment of xenografted mice with physical and/or chemotherapeutic agents; (5) verification of the selectivity of the effects on plasma miRNA content of miRNA targeting and relative delivery approaches; (6) usage as key tools for the comparison of different analytical strategies including, among others, different PCR/RT-qPCR and NGS platforms, instruments and protocols, as well as PCR-free methods ${ }^{[84-86]}$. Among possible limits of 
the mouse xenograft model systems here presented are the differences between man and mouse with respect to ctDNA and microRNA dinamics in respect to their vasculature. Therefore we should carefully consider the sharply different ratios between the dimension of implanted tumors, the mouse body weight and the blood volume on one hand and those related the same parameters (i.e., tumor weight, body weight and blood total volume) in CRC patients. In this respect the analysis of the miRNome in liquid biopsy obtained when tumors of different dimensions are employed in mouse xenograft model systems might clarify whether the ratio between tumor size and mouse body weight or blood volume might affect the results. This might also be of interest for developing algorithms in human clinical settings.

\section{DECLARATIONS}

\section{Authors' contributions}

Revised and approved the final manuscript: Gasparello J, Allegretti M, Papi C, Giordani E, Giacomini P, Gambari R, Finotti A

Wrote the manuscript: Allegretti M, Giacomini P, Gambari R, Finotti A

Performed the literature search: Allegretti M, Giacomini P, Gambari R, Finotti A

Critically analyzed the existing literature: Allegretti M, Giacomini P, Gambari R, Finotti A

Designed the figures and created the tables: Gasparello J, Papi C, Giordani E, Gambari R, Finotti A

\section{Availability of data and materials}

Not applicable.

\section{Financial support and sponsorship}

This work was supported by the European Union (EU) Horizon 2020 Research and Innovation Programme: project ULTRAsensitive PLAsmonic devices for early CAncer Diagnosis (ULTRAPLACAD) (633937); Associazione Italiana per la Ricerca sul Cancro (AIRC) (13575) to Gambari R, (14204, 19052) to Giacomini P. Allegretti M is the recipient of a three-year AIRC fellowship (id. 19503). This study was also supported by the Interuniversity Consortium for the Biotechnology, Italy.

\section{Conflicts of interest}

The author declared that there are no conflicts of interest.

\section{Ethical approval and consent to participate}

Not applicable.

\section{Consent for publication}

Not applicable.

\section{Copyright}

(c) The Author(s) 2019.

\section{REFERENCES}

1. Heitzer E, Auer M, Ulz P, Geigl JB, Speicher MR. Circulating tumor cells and DNA as liquid biopsies. Genome Med 2013;5:73.

2. Bettegowda C, Sausen M, Leary RJ, Kinde I, Wang Y, et al. Detection of circulating tumor DNA in early- and late-stage human malignancies. Sci Transl Med 2014;6:224ra24.

3. Newman AM, Bratman SV, To J, Wynne JF, Eclov NC, et al. An ultrasensitive method for quantitating circulating tumor DNA with broad patient coverage. Nat Med 2014;20:548-54.

4. Breitbach S, Tug S, Helmig S, Zahn D, Kubiak T, et al. Direct quantification of cell-free, circulating DNA from unpurified plasma. PLoS One 2014;9:e87838.

5. Heitzer E, Ulz P, Geigl JB. Circulating tumor DNA as a liquid biopsy for cancer. Clin Chem 2015;61:112-23.

6. Diehl F, Schmidt K, Choti MA, Romans K, Goodman S, et al. Circulating mutant DNA to assess tumor dynamics. Nat Med 
2008;14:985-90

7. Leon SA, Shapiro B, Sklaroff DM, Yaros MJ. Free DNA in the serum of cancer patients and the effect of therapy. Cancer Res 1977;37:646-50.

8. Sozzi G, Conte D, Mariani L, Lo Vullo S, Roz L, et al. Analysis of circulating tumor DNA in plasma at diagnosis and during follow-up of lung cancer patients. Cancer Res 2001;61:4675-8

9. Spindler KL, Pallisgaard N, Vogelius I Jakobsen A. Quantitative cell-free DNA, KRAS, and BRAF mutations in plasma from patients with metastatic colorectal cancer during treatment with cetuximab and irinotecan. Clin Cancer Res 2012;18:1177-85.

10. Perkins G, Yap TA, Pope L, Cassidy AM, Dukes JP, et al. Multi-purpose utility of circulating plasma DNA testing in patients with advanced cancers. PLoS One 2012;7:e47020.

11. Ignatiadis M, Lee M, Jeffrey SS. Circulating tumor cells and circulating tumor DNA: challenges and opportunities on the path to clinical utility. Clin Cancer Res 2015;21:4786-800.

12. Krebs MG, Hou JM, Ward TH, Blackhall FH, Dive C. Circulating tumour cells: their utility in cancer management and predicting outcomes. Ther Adv Med Oncol 2010;2:351-65.

13. Millner LM, Linder MW, Valdes R. Circulating tumor cells: a review of present methods and the need to identify heterogeneous phenotypes. Ann Clin Lab Sci 2013;43:295-304.

14. Kuipers EJ, Spaander MC. Personalized screening for colorectal cancer. Nat Rev Gastroenterol Hepatol 2018;15:391-2.

15. Hardingham JE, Grover P, Winter M, Hewett PJ, Price TJ, et al. Detection and clinical significance of circulating tumor cells in colorectal cancer-20 years of progress. Mol Med 2015;21 Suppl 1:S25-31.

16. Kloten V, Rüchel N, Brüchle NO, Gasthaus J, Freudenmacher N, et al. Liquid biopsy in colon cancer: comparison of different circulating DNA extraction systems following absolute quantification of KRAS mutations using Intplex allele-specific PCR. Oncotarget 2017;8:86253-63.

17. Thomsen CEB, Appelt AL, Andersen RF, Lindebjerg J, Jensen LH, et al.The prognostic value of simultaneous tumor and serum RAS/ RAF mutations in localized colon cancer. Cancer Med 2017;6:928-36.

18. Veldore VH, Choughule A, Routhu T, Mandloi N, Noronha V, et al. Validation of liquid biopsy: plasma cell-free DNA testing in clinical management of advanced non- small cell lung cancer. Lung Cancer (Auckl) 2018;9:1-11.

19. Anfossi S, Babayan A, Pantel K, Calin GA. Clinical utility of circulating non-coding RNAs - an update. Nat Rev Clin Oncol 2018;15:541-63.

20. Izzotti A, Carozzo S, Pulliero A, Zhabayeva D, Ravetti JL, et al. Extracellular microRNA in liquid biopsy: applicability in cancer diagnosis and prevention. Am J Cancer Res 2016;6:1461-93.

21. Huang Z, Huang D, Ni S, Peng Z, Sheng W, et al. Plasma microRNAs are promising novel biomarkers for early detection of colorectal cancer. Int J Cancer 2010;127:118-26.

22. Ogata-Kawata H, Izumiya M, Kurioka D, Honma Y, Yamada Y, et al. Circulating exosomal microRNAs as biomarkers of colon cancer. PLoS One 2014;9:e92921.

23. Ng EK, Chong WW, Jin H, Lam EK, Shin VY, et al. Differential expression of microRNAs in plasma of patients with colorectal cancer: a potential marker for colorectal cancer screening. Gut 2009;58:1375-81.

24. Zheng G, Du L, Yang X, Zhang X, Wang L, et al. Serum microRNA panel as biomarkers for early diagnosis of colorectal adenocarcinoma. Br J Cancer 2014;111:1985-92.

25. Ghelani HS, Rachchh MA, Gokani RH. MicroRNAs as newer therapeutic targets: a big hope from a tiny player. J Pharmacol Pharmacother 2012;3:217-27.

26. Krol J, Loedige I, Filipowicz W. The widespread regulation of microRNA biogenesis, function and decay. Nat Rev Genet 2010;11:597-610.

27. Gambari R, Fabbri E, Borgatti M, Lampronti I, Finotti A, et al. Targeting microRNAs involved in human diseases: a novel approach for modification of gene expression and drug development. Biochem Pharmacol 2011;82:1416-29.

28. Piva R, Spandidos D, Gambari R. From microRNA functions to microRNA therapeutics: novel targets and novel drugs in breast cancer research and treatment. Int J Oncol 2013;43:985-94.

29. Gambari R, Brognara E, Spandidos DA, Fabbri E. Targeting oncomiRNAs and mimicking tumor suppressor miRNAs: New trends in the development of miRNA therapeutic strategies in oncology. Int J Oncol 2016;49:5-32.

30. Nishida-Aoki N, Ochiya T. Interactions between cancer cells and normal cells via miRNAs in extracellular vesicles. Cell Mol Life Sci 2015;72:1849-61.

31. Schetter AJ, Okayama H, Harris CC. The role of microRNAs in colorectal cancer. Cancer J 2012;18:244-52.

32. Gheinani AH, Vögeli M, Baumgartner U, Vassella E, Draeger A, et al. Improved isolation strategies to increase the yield and purity of human urinary exosomes for biomarker discovery. Sci Rep 2018;8:3945.

33. da Silveira JC, Andrade GM, Del Collado M, Sampaio RV, Sangalli JR, et al. Supplementation with small-extracellular vesicles from ovarian follicular fluid during in vitro production modulates bovine embryo development. PLoS One 2017;12:e179451.

34. Halvorsen AR, Helland A, Gromov P, Wielenga VT, Talman MM, et al. Profiling of microRNAs in tumor interstitial fluid of breast tumors - a novel resource to identify biomarkers for prognostic classification and detection of cancer. Mol Oncol 2017;11:220-34.

35. Valentino A, Reclusa P, Sirera R, Giallombardo M, Camps C, et al. Exosomal microRNAs in liquid biopsies: future biomarkers for prostate cancer. Clin Transl Oncol 2017;19:651-7.

36. Wecker T, Hoffmeier K, Plötner A, Grüning BA, Horres R, et al. MicroRNA Profiling in Aqueous Humor of Individual Human Eyes by Next-Generation Sequencing. Invest Ophthalmol Vis Sci 2016;57:1706-13.

37. Pu XX, Huang GL, Guo HQ, Guo CC, Li H, et al. Circulating miR-221 directly amplified from plasma is a potential diagnostic and 
prognostic marker of colorectal cancer and is correlated with p53 expression. J Gastroenterol Hepatol 2010;25:1674-80.

38. Liu GH, Zhou ZG, Chen R, Wang MJ, Zhou B, et al. Serum miR-21 and miR-92a as biomarkers in the diagnosis and prognosis of colorectal cancer. Tumour Biol 2013;34:2175-81.

39. Cheng H, Zhang L, Cogdell DE, Zheng H, Schetter AJ, et al. Circulating plasma MiR- 141 is a novel biomarker for metastatic colon cancer and predicts poor prognosis. PLoS One 2011;6:e17745.

40. Lv ZC, Fan YS, Chen HB, Zhao DW. Investigation of microRNA-155 as a serum diagnostic and prognostic biomarker for colorectal cancer. Tumour Biol 2015;36:1619-25.

41. Krawczyk P, Powrózek T, Olesiński T, Dmitruk A, Dziwota J, et al. Evaluation of miR-506 and miR-4316 expression in early and noninvasive diagnosis of colorectal cancer. Int J Colorectal Dis 2017;32:1057-60.

42. Liu C, Eng C, Shen J, Lu Y, Takata Y, et al. Serum exosomal miR-4772-3p is a predictor of tumor recurrence in stage II and III colon cancer. Oncotarget 2016;7:76250-60.

43. Li N, Ma J, Guarnera MA, Fang H, Cai L, et al. Digital PCR quantification of miRNAs in sputum for diagnosis of lung cancer. J Cancer Res Clin Oncol 2014;140:145-50.

44. Leng Q, Lin Y, Jiang F, Lee CJ, Zhan M, et al. A plasma miRNA signature for lung cancer early detection. Oncotarget 2017;8:111902-11.

45. Margue C, Reinsbach S, Philippidou D, Beaume N, Walters C, et al. Comparison of a healthy miRNome with melanoma patient miRNomes: are microRNAs suitable serum biomarkers for cancer? Oncotarget 2015;6:12110-27.

46. Müllauer L. Next generation sequencing: clinical applications in solid tumours. Memo 2017;10:244-7.

47. Giuffrida MC, Zanoli LM, D'Agata R, Finotti A, Gambari R, et al. Isothermal circular- strand-displacement polymerization of DNA and microRNA in digital microfluidic devices. Anal Bioanal Chem 2015;407:1533-43.

48. Guo Q, Yang X, Wang K, Tan W, Li W, et al. Sensitive fluorescence detection of nucleic acids based on isothermal circular stranddisplacement polymerization reaction. Nucleic Acids Res 2009;37:e20.

49. D'Agata R, Breveglieri G, Zanoli LM, Borgatti M, Spoto G, et al. Direct detection of point mutations in nonamplified human genomic DNA. Anal Chem 2011;83:8711-7.

50. Bellassai N, Spoto G. Biosensors for liquid biopsy: circulating nucleic acids to diagnose and treat cancer. Anal Bioanal Chem 2016;408:7255-64.

51. Finotti A, Allegretti M, Gasparello J, Giacomini P, Spandidos DA, et al. Liquid biopsy and PCR-free ultrasensitive detection systems in oncology. Int J Oncol 2018;53:1395-1434.

52. Mitchell PS, Parkin RK, Kroh EM, Fritz BR, Wyman SK, et al. Circulating microRNAs as stable blood-based markers for cancer detection. Proc Natl Acad Sci U S A 2008;105:10513-8.

53. Hu Z, Chen X, Zhao Y, Tian T, Jin G, et al. Serum microRNA signatures identified in a genome-wide serum microRNA expression profiling predict survival of non-small-cell lung cancer. J Clin Oncol 2010;28:1721-6.

54. Selth LA, Townley S, Gillis JL, Ochnik AM, Murti K, et al. Discovery of circulating microRNAs associated with human prostate cancer using a mouse model of disease. Int J Cancer 2012;131:652-61.

55. Gasparello J, Allegretti M, Tremante E, Fabbri E, Amoreo CA, et al. Liquid biopsy in mice bearing colorectal carcinoma xenografts: gateways regulating the levels of circulating tumor DNA (ctDNA) and miRNA (ctmiRNA). J Exp Clin Cancer Res 2018;37:124.

56. Greystoke A, Ayub M, Rothwell DG, Morris D, Burt D, et al. Development of a circulating miRNA assay to monitor tumor burden: From mouse to man. Mol Oncol 2016;10:282-91.

57. Chapin SC, Doyle PS. Ultrasensitive multiplexed microRNA quantification on encoded gel microparticles using rolling circle amplification. Anal Chem 2011;83:7179-85.

58. Williams MR, Stedtfeld RD, Stedtfeld TM, Tiedje JM, Hashsham SA. Quantification of microRNAs directly from body fluids using a base-stacking isothermal amplification method in a point-of-care device. Biomed Microdevices 2017;19:45.

59. Valoczi A, Hornyik C, Varga N, Burgyan J, Kauppinen S, et al. Sensitive and specific detection of microRNAs by northern blot analysis using LNA-modified oligonucleotide probes. Nucleic Acids Res 2004;32:e175.

60. Lu J, Getz G, Miska EA, Alvarez-Saavedra E, Lamb J, et al. MicroRNA expression profiles classify human cancers. Nature 2005;435:834-8.

61. Garcia-Olmo DC, Gutierrez-Gonzalez L, Ruiz-Piqueras R, Picazo MG, Garcia-Olmo D. Detection of circulating tumor cells and of tumor DNA in plasma during tumor progression in rats. Cancer Lett 2005;217:115-23.

62. Rago C, Huso DL, Diehl F, Karim B, Liu G, et al. Serial assessment of human tumor burdens in mice by the analysis of circulating DNA. Cancer Res 2007;67:9364-70.

63. Thierry AR, Mouliere F, Gongora C, Ollier J, Robert B, et al. Origin and quantification of circulating DNA in mice with human colorectal cancer xenografts. Nucleic Acids Res 2010;38:6159-75

64. Goodale D, Phay C, Postenka CO, Keeney M, Allan AL. Characterization of tumor cell dissemination patterns in preclinical models of cancer metastasis using flow cytometry and laser scanning cytometry. Cytometry A 2009;75A:344-55.

65. Fan ZC, Yan J, Liu GD, Tan XY, Weng XF, et al. Real-time monitoring of rare circulating hepatocellular carcinoma cells in an orthotopic model by in vivo flow cytometry assesses resection on metastasis. Cancer Res 2012;72:2683-91.

66. Welch DR. Technical considerations for studying cancer metastasis in vivo. Clin Exp Metastasis 1997;15:272-306.

67. Kersten K, de Visser KE, van Miltenburg MH, Jonkers J. Genetically engineered mouse models in oncology research and cancer medicine. EMBO Mol Med 2017;9:137-53.

68. Gengenbacher N, Singhal M, Augustin HG. Preclinical mouse solid tumour models: status quo, challenges and perspectives. Nat Rev Cancer 2017;17:751-65. 
69. Giuliano M, Herrera S, Christiny P, Shaw C, Creighton CJ, et al. Circulating and disseminated tumor cells from breast cancer patientderived xenograft-bearing mice as a novel model to study metastasis. Breast Cancer Res 2015;17:3.

70. Waters PS, McDermott AM, Wall D, Heneghan HM, Miller N, et al. Relationship between circulating and tissue microRNAs in a murine model of breast cancer. PLoS One 2012;7:e50459.

71. Zhang G, Zhang W, Li B, Stringer-Reasor E, Chu C, et al. MicroRNA-200c and microRNA- 141 are regulated by a FOXP3-KAT2B axis and associated with tumor metastasis in breast cancer. Breast Cancer Res 2017;19:73.

72. Zhou ZP, Wang LP, Hong ZS, Qiu CZ, Wang MZ, et al. Silencing GOLPH3 gene expression reverses resistance to cisplatin in HT29 colon cancer cells via multiple signaling pathways. Int J Oncol 2018;53:1183-92.

73. Bai B, Chen X, Zhang R, Wang X, Jiang Y, et al. Dual-agonist occupancy of orexin receptor 1 and cholecystokinin A receptor heterodimers decreases G-protein-dependent signaling and migration in the human colon cancer cell line HT-29. Biochim Biophys Acta Mol Cell Res 2017;1864:1153-64.

74. Maeda K, Maeda T, Qi Y. In vitro and in vivo induction of human LoVo cells into apoptotic process by non-invasive microwave treatment: a potentially novel approach for physical therapy of human colorectal cancer. Oncol Rep 2004;11:771-5.

75. Qin J, Luo M. MicroRNA-221 promotes colorectal cancer cell invasion and metastasis by targeting RECK. FEBS Lett 2014;588:99-104.

76. Xu K, Liang X, Shen K, Sun L, Cui D, et al. MiR-222 modulates multidrug resistance in human colorectal carcinoma by downregulating ADAM-17. Exp Cell Res 2012;318:2168-77.

77. Dou H, Wang Y, Su G, Zhao S. Decreased plasma let-7c and miR-152 as noninvasive biomarker for non-small-cell lung cancer. Int J Clin Exp Med 2015;8:9291-8.

78. Yu H, Jiang L, Sun C, Li Guo L, Lin M, et al. Decreased circulating miR-375: a potential biomarker for patients with non-small-cell lung cancer. Gene 2014;534:60-5.

79. Heneghan HM, Miller N, Lowery AJ, Sweeney KJ, Newell J, et al. Circulating microRNAs as novel minimally invasive biomarkers for breast cancer. Ann Surg 2010;251:499-505.

80. Pérez-Ramírez C, Cañadas-Garre M, Robles AI, Molina MÁ, Faus-Dáder MJ, et al. Liquid biopsy in early stage lung cancer. Transl Lung Cancer Res 2016;5:517-24.

81. Quandt D, Dieter Zucht H, Amann A, Wulf-Goldenberg A, Borrebaeck C, et al. Implementing liquid biopsies into clinical decision making for cancer immunotherapy. Oncotarget 2018;8:48507-20.

82. Nikolaev S, Lemmens L, Koessler T, Blouin JL, Nouspikel T. Circulating tumoral DNA: Preanalytical validation and quality control in a diagnostic laboratory. Anal Biochem 2018;542:34-9.

83. Barr J, Caballería J, Martínez-Arranz I, Domínguez-Díez A, Alonso C, et al. Obesity- dependent metabolic signatures associated with nonalcoholic fatty liver disease progression. J Proteome Res 2012;11:2521-32.

84. Kim J, Easley CJ. Isothermal DNA amplification in bioanalysis: strategies and applications. Bioanalysis 2011;3:227-39.

85. D'Agata R, Spoto G. Surface plasmon resonance imaging for nucleic acid detection. Anal Bioanal Chem 2013;405:573-84.

86. Das J, Ivanov I, Montermini L, Rak J, Sargent EH, et al. An electrochemical clamp assay for direct, rapid analysis of circulating nucleic acids in serum. Nat Chem 2015;7:569-75. 